\title{
The Value of Teaching Creativity in Adult Education
}

\author{
Kuan Chen Tsai \\ University of the Incarnate Word, USA
}

Received: July 23, 2012

doi:10.5430/ijhe.v1n2p84
Accepted: August 1, $2012 \quad$ Online Published: August 5, 2012

URL: http://dx.doi.org/10.5430/ijhe.v1n2p84

\begin{abstract}
In today's postmodern world, change is the only thing for sure. As a result, creative capacity is the key. Learning creative thinking in fact is a useful vehicle for adult learners to polish their abilities and orientate the world around them. This article attempts to review creativity-related literature and to provide some salient considerations for adult educators with the desire to promote creativity in the classrooms. To begin, the definition of creativity was disclosed. Then the process of creativity was reviewed. Following this line, several factors, including personality traits, knowledge and expertise, motivation and self-efficacy, learning style and thinking style, teaching approaches, assessment and reward, and environment, that might facilitate or stifle creativity were discussed. Finally, some suggestions for adult educators were provided.
\end{abstract}

Keywords: Adult education, Adult learners, Continuing education, Creativity

\section{Introduction}

In today's postmodern world, change is the only thing for sure. As a result, creative capacity is the key. How can teachers orchestrate students' creativity? Teaching students to think creatively is perhaps the efficacious and comprehensive skill necessary to leading change in the future (Harding, 2010). Therefore, unlocking the power of imagination to transform creative thoughts into creative actions becomes significant in the educational agenda. Teachers should cultivate the ability of students to think openly and generate novel ideas (Wilson, 2009). Above all, societies and schools both play an important role on creativity (Niu \& Sternberg, 2003).

The capacity to generate novel ideas for problem solving could be viewed as one of many human treasures (Mouchiroud \& Lubart, 2002). Creativity is more obviously found in young children than in adults because of alignment of intellectual conformity, which in turn suppresses their creative potential (Sternberg, 2006). A number of studies revealed the age-related correlational differences between adolescents and young adults in creative achievement (Barron \& Harrington, 1981). As a result, it is vital to bring creativity into the adult classroom and hopefully that action could lead to promising results. In psychology, creativity is pictured from diverse perspectives as a mental and social process, reflecting human values on objects (Magno, 2009). Most creativity researchers generally acknowledge that creativity is not synonymous with intelligence (Runco, 2004). However, creativity demands tremendous resource from knowledge and domain-relevant skills (Mumford, Hunter, \& Byrne, 2009). Welkener (2004) argued that creativity needs more involvement than intellect; namely, it engages the whole person.

In adult education, Edelson (1999) found the dimension of creativity is neglected, especially creative thinking. It needs more focus on examining creativity development in adult learners. Although some adult educators have made a plea for promoting creativity in adult education (e.g., Edelson, 1999; Hickson \& Housley, 1997; Lones, 2000), it still lacks momentum. More creative energy should be poured into adult classrooms. Accordingly, the purpose of this article is to review creativity-related literature and to provide some salient considerations for adult educators with the desire to promote creativity in the classrooms. To begin, the definition of creativity will be disclosed. Then the process of creativity will be reviewed. Following this line, several factors that might facilitate or stifle creativity will be discussed. Finally, some suggestions for adult educators will be provided.

\section{Defining Creativity}

In early times, creativity was viewed as mystery. Creative action was credited to the visitation of the Muse or the divine force; creative geniuses were serendipitously inspired by divine intervention (Haring-Smith, 2006; Simonton, 2006). For example, Plato argued this inspiration is the gift of Gods (Plato: The Laws). The notion of creativity under the umbrella of the divine entity was dominant in the history of Western mindset for centuries. In the Age of Enlightenment, the concept of creativity shifted from divine to individual, as emphasis shifted to the achievement of science and technology (Craft, Gardner, \& Claxton, 2008; Niu \& Sternberg, 2006). 
Creativity is an elusive construct that is difficult to define. Theorists do not agree entirely on a single definition (Amabile, 1996; Ya-Hui, 2009), but various definitions share a number of common themes (e.g., novelty and utility) (Runco, 2003; Torrance, 1995). There is general agreement within creativity researchers that creativity is a complex process where the interactive relationship is located within four dimensions: creative persons, the cognitive processes of creativity, products of creative performance, and social and cultural contexts (Batey \& Furnham, 2006; Zimmerman, 2009). Therefore, creativity is defined as a process, which transforms the novel ideas into useful products, where there is the interplay between the individual and the context (Hunter, Bedell, \& Mumford, 2007; Oldham \& Cummings, 1996; Woodman, Sawyer, \& Griffin, 1993).

\section{Creative Process}

Based on literature, there are four overlapping stages in the process of creative thinking: (a) preparation, individuals taking initial actions (e.g., searching, collecting, and listening) to confront the challenge, (b) incubation, creative insight taking hold which in turn leads to an "Aha!" moment, (c) illumination, individuals experiencing various possibilities and having a creativity leap via clear insights and intuition, and (d) verification, a sense-making phase to finalize the decision (Dineen \& Collins, 2005; Parker, 2005; Wallas, 1926).

Extended this line, Mumford, Mobley, Uhlman, Reiter-Palmon, and Doares (1991) suggested that processing mechanisms should generate new understanding derived from existing knowledge. They submitted eight core processes in terms of creative problem solving: (a) problem construction or problem finding, (b) information gathering, (c) concept search and selection, (d) conceptual combination, (e) idea generation, (f) idea evaluation, (g) implementation, and (h) action monitoring. Basically, this model underscores the problem construction, category search, and category combination, and reorganization. In addition, this dynamic model allows for cycling between different phases of processes.

Experiencing this creative process needs time. As a caveat given by Harding (2010), "transforming the ability to think creatively into the ability to act creatively requires an enormous amount of patience" (p. 52). As a result, teachers should provide the ample space for expected results for the sake of developing creativity. In addition, Mumford (2000) depicted that one way to manage creative individuals is to provide sufficient thinking time, thereby allowing ideas to percolate. However, with regard to creating, time allocation and management should take into account the nature and complexity of tasks. Above all, time is valuable capital.

\section{Factors Affecting Creativity Development}

Creativity scholars have identified several possible factors that facilitate or inhibit creative performance. For instance, Woodman et al. (1993) provided an interactionist perspective on organizational creativity. The comprehensive framework has great promise for explaining the complex mosaic of three levels (individual, group, and organization) of creative behavior shaped by various potential variables. At the first level, an individual creative output is determined by antecedent conditions (e.g., biographical factors), cognitive ability (e.g., divergent thinking), disposition (e.g., self-esteem), knowledge, motivation, social influences (e.g., rewards), and contextual influences (e.g., physical environment). At the group level, it involves the interaction of the group members, group process, and contextual influences. Finally, organizational creativity is affected by its component groups and contextual factors (e.g., culture and resource). The key feature of this model is its utility to capture leverage across levels of analysis, which specifically identifies the group and organizational attributes that either facilitate or inhibit creative action in complicated social systems.

A demand in fostering creativity has become a universalized discourse across different nations (Craft, Gardner, \& Claxton, 2008; Newton \& Newton, 2009). The function of education serves as the building block of human capital through equipping students with knowledge and creative capacities (Lin, 2011; NACCCE, 1999). Policymaking and curriculum reform were carried out in order to fit this need (Feldman \& Benjamin, 2006; Shaheen, 2010). Within education, the most salient considerations for promoting creativity are personality, knowledge, motivation, thinking and learning styles, teaching styles, assessments and rewards, and environment.

\subsection{Personality Traits}

Since the 1950s, the personality profile associated with highly creative achievers was a hot issue in creativity research. The main thread of investigations is to question "whether highly creative people have common characteristics across fields and to examine the major differences among highly creative people" (Ch·vez-Eakle, Lara, $\&$ Cruz-Fuentes, 2006, p. 28). Numerous researchers have supported the fact that certain clusters of personality attributions are related to creative functioning, involving self-confidence, independence, openness to experience, willingness to take risks, attraction to complexity, toleration of ambiguity, flexibility, and intuition (Cummings \& 
Oldham, 1997; James \& Asmus, 2000; Kurtzberg \& Amabile, 2001; Mumford, 2000; Oldham \& Cummings, 1996; Sternberg, 2006).

Kim, Hon, and Deog-Ro (2010) found a positive linkage between proactive (rather than passive) personality and creativity by means of an Asian context. However, they suggested personality does not entirely determine individual creativity; rather, trait-relevant situational factors also play an important role in shaping individual creativity. On a similar line, Sosik, Kahai, and Avolio's (1998) findings provided support for this notion. After Prabhu, Sutton, and Sauser (2008) reviewed the literature, they examined the relationship between three personality traits (openness to experience, self-efficacy, and perseverance) and creativity. The empirical results demonstrated that creativity was only closely related to openness to experience and self-efficacy.

\subsection{Knowledge and Expertise}

Gardner (1993) discovered that creative geniuses take about ten years to master their fields before making astounding contributions. Therefore, the driving force to novel ideas through completion "come[s] only after the expert knowledge is acquired and mastered" (Edelson, 1999, p. 5). Based on Batey and Furnham's (2006) literature review, creativity stems from both intelligence and knowledge. More specifically, "creativity would be an extension of ordinary intelligence" (p. 374). However, they reminded us "intelligence can be seen as necessary for creative achievement, but not sufficient" (p. 372).

Amabile (1998) proposed that individuals have creative potential which is affected by three factors: expertise, creative-thinking skills, and motivation. Expertise and creative thinking are individuals' natural reservoir. Ford (1996) argued that individuals' capacity for creativity consists of three variables: domain-related knowledge, behavioral abilities, and creative-thinking abilities. Expertise is a prerequisite to creative performance. Expertise essentially plays an important role in confronting creative problem solving. Furthermore, required skills also have great weights on affecting creative performance (Mumford, 2000).

\subsection{Motivation and Self-Efficacy}

In general, research supported that under the conditions of giving ownership, valuing input, and seeking one's own interests, the intrinsic motivation of learners will increase (Dineen \& Collins, 2005). A strong body of work supports that motivation is a core factor to influence creativity (Amabile, 1998; Hennessey, 2003; Tierney, Farmer, \& Graen, 1999; Woodman et al., 1993). There are two types of motivation: extrinsic and intrinsic, the latter being far more essential for creativity. Hennessey (2003) pointed "intrinsic motivation is a primary driving force behind the creative process" (p. 266). However, Mumford (2000) noticed that "creative work calls for both intrinsic and extrinsic motivation operating in a synergistic fashion" (p. 324). Therefore, it is likelihood that teachers should utilize both intrinsic and extrinsic motivation at different situations.

There are some potential variables correlated to students' creative self-efficacy: motivation, perceptions, schooling experience, and academic beliefs and behaviors. The focus of considerable empirical evidence has demonstrated the reciprocal links between efficacy beliefs and creativity outcomes (Beghetto, 2006). When students are confident about their capabilities to be creative and thus expect favorable results from their creative efforts, they may develop positive evaluative judgments and emotions regarding creativity. Creativity efficacy and positive attitude toward creativity function as cognitive and affective bases of individual creative performance. Therefore, creativity efficacy may influence positive attitudes toward creativity. Beghetto's (2006) study showed the positive association between students' motivational beliefs and teachers' feedback on creative performance and their creative self-efficacy.

\subsection{Learning Styles and Thinking Styles}

The learning map provided by Kolb identifies four types of learner, including accommodators, convergers, divergers, and assimilators. Those learning styles are derived from four perceptions of learning modes: concrete experience, reflective observation, abstract conceptualization, and active experimentation (reviewed by Nilson, 2010). Kolb's model implies the fact that teachers should design a course with diverse learning activities that caters to learners with distinct learning styles in order to maximize the creativity potential and learning results. In other words, the format of the lecture alone may not be beneficial for promoting creative thinking. Various cognitive processes are regarded to either hinder or facilitate creativity. For instance, functional fixedness and cognitive set, which are defined as inability to explore alternative solutions because of cognitive rigidity, are stumbling blocks to produce novel ideas (Ruscio \& Amabile, 1999). Creative ideas are expected to emerge from multiple agencies of conceptions and tactics (Mumford, 2000).

Divergent thinking and associational skills are one of the most frequently cited in literature of creative abilities. The assessment of divergent thinking is to examine the possible solutions for an open-ended problem. The technique of 
associational abilities is using analogies and metaphors to discover unusual relationships (Ford, 1996). The test regarding individual performance capacities is judged either by quantity of alternative solutions or by quality and originality of the solution. More specifically creativity tests successfully demonstrate both the ability to generate solutions and creative thinking skills, including "problem construction, information encoding, category selection, and category combination and reorganization" (Mumford, 1995, p. 408). Although the divergent thinking is important to generate many solutions, critical evaluation of the ideas is also important for the process of problem solving (Williams, 2004).

\subsection{Teaching Approaches}

Teachers, in fact, stand in a unique position in fostering creativity in the classroom. Teachers' beliefs about classroom practice appear to shape their goals for creativity. Thus, teachers should set an appropriate learning goal to encourage and inspire students to pursue creative achievements. Teaching styles most conducive to satisfaction of developing creative capacity are those which focus on autonomy, trust, independent learning, and individual considerations (Dineen \& Collins, 2005). Student-centered learning experience should also be grounded in the classroom, thereby promoting creative thinking. Most important, teachers as facilitators should provide opportunities for active engagement by learners. Learning by authority (e.g., a classroom teacher) consists partly learner abilities (e.g., recognition, memory, and logical reasoning), in contrast to creative learning involving the abilities of evaluation, divergent production, and redefinition (Torrance, 1977). Further, creativity in learners is encouraged by (a) supportive, student-centered environments, (b) non-hierarchical teaching styles, (c) teaching methods and tasks, and (d) assessment systems (Dineen, Samuel, \& Livesey, 2005, p. 159).

Some strategies might be favorable to creative actions in students: group learning, creative writing, one-minute paper, role-playing, and problem-based leaning (Nilson, 2010). The key is, as Dineen and Collins (2005) pointed out, "creative learning relies on experiential, often intuitive learning" (p. 48). Further, the research showed that students viewed teaching style and methods as an important factor for their creative success results (Dineen et al., 2005). More specifically, three favorable traits of teaching styles are friendly, encouraging, and enthusiastic.

\subsection{Assessment and Reward}

Research implies that expected evaluation may have dysfunctional consequences on creativity through a detrimental effect on intrinsic motivation and negatively affecting cognitive activities (Amabile, 1996). The possible reason is that individuals' evaluation apprehension could force people to focus on extrinsic factors, therefore away from the task per se. Most important, this result may lead students to shun risk-taking and exploring the horizon of possibilities, which is a key component of creativity (Shalley, 1995). Nevertheless, under the umbrella of social-psychological investigations, researchers have recognized that "under certain specific conditions, the expectation of reward can sometimes increase levels of extrinsic motivation without having any negative impact on intrinsic motivation or performance" (Hennessey, 2003, p. 259).

In business settings, the research findings display that expectations of evaluation, under certain conditions, could be beneficial for individuals' creativity, depending on the type of expected evaluation. If the goal is pursuing high quality of creativity and productivity, people should work alone without expected evaluation (Shalley, 1995). Furthermore, a creativity goal is favorable to foster creative performance but is unfriendly to productivity. Through setting creative goals and expectations, teachers could provide excellent modeling of commitment to their students and also help them develop an intrinsic reward system of their own. Shalley (1995) believed that "a creativity goal appears to motivate individuals to direct their attention and effort toward producing novel and appropriate responses... Goal setting can be an effective mechanism for enhancing performance as long as goals are set for all desired performance dimensions"(p. 499).

\subsection{Environment}

The literature reviewed by Hunter et al. (2007) demonstrated that climate appraisals could be indices of creative achievement in reality. Receptivity beliefs imposed by organizational settings are also a catalyst for creative actions. A positive history of success could reinforce the likelihood of creative endeavors, vis-a-vis previous negative experiences. To some extent it is related to capability beliefs or self-efficacy. The strong image of positive capability confidence is very favorable for people's creativity (Ford, 1996). Moreover, the research on organizational climate provided some useful points for stimulating creativity and innovation: trust and support environment for fostering new ideas and changes; the willingness to challenge the fixed construct; prestige-free atmosphere and an attitude toward tolerance of uncertainty (Ekvall \& Ryhammar, 1999). 
Amabile (1998) recommended that leaders should establish an organizational environment for subordinates where they can feel safe to try out innovative thinking without the fear of punishment for failure. This argument could also apply to a classroom. One important role that teachers can play to foster creativity among students is to establish a classroom without fear of voicing innovative approaches. Furthermore, most of the time the creative enterprise happens in a team setting; thus, the role of teacher-leader has a tendency to markedly impact creative efforts. In light of the nature of creative work, which is ambiguous, risky, and subject to criticism, supportive supervision appears to make contributions to creativity (Mumford, 2000).

\section{Some Suggestions for Adult Educators}

When examining those possible factors that influence creative performance, three general considerations for educators should be included. First, some traditional teaching approaches should be adjusted or fundamentally changed. For example, is an analytical skill suitable for every class scenario? Second, the education system should provide the kind of trainings that promote creativity development on both teachers and students side. Finally, teachers should encourage diversity in the classroom allowing creative individuals to express their potential. In fact, as Niu and Sterberg (2003) recommended, teachers should take the lead to promptly encourage students to challenge the norms, be critical reflection and be imaginative thinking, and involve more in creative self-exploratory activities.

Edelson (1999) provided some approaches in which adult and continuing educators encourage creativity: organizing for innovation, enhancing motivation to create, promoting self-efficacy, developing expertise, providing time for the generation of new ideas, feedback and reality checking, playing at work, creating a personalized environment, planning for accidents, and building group interaction (pp. 9-11).

Torrance (1977) suggested several procedures that are beneficial to promote creative behavior: (1) give purpose to creative activities, (2) provide experiences which make learners more sensitive to environmental stimuli, (3) develop a constructive attitude toward the information taught, (4) provide adequate warm-up for creative attitudes, (5) avoid giving evaluative comments too frequently during practice problems or activities, (6) to evoke originality in thinking, make it clear that such thinking is expected and will be rewarded (pp. 27-28).

Mumford (2000) provided a number of useful suggestions regarding generating new ideas: (1) identify key questions, (2) distribute sufficient time for elaboration, and (3) minimize the demands of immediate results. Additionally, with respect to goals and rewards in creative efforts, Mumford (2000) offered three perspectives of tackling that issue: (1) focus on performance objectives with regard to creative elements of the task, (2) evaluate progress rather than outcomes, thereby avoiding the block of creative flow, and (3) capitalize a mix of rewards on a basis of progress with objectives.

In order to maximize the effects of the creative development for adult learners, at least three levels (curriculum, educators, and learners) should be considered:

\section{Curriculum}

(1) Institutional administrators and educators with the agenda of promoting creativity should work hand in hand to facilitate creative development for adult learners.

(2) Curriculum should be appropriately flexible and offer opportunities for creative behavior.

\section{Educators}

(3) With regards to instructional style, the heuristic approach is more favorable than algorithmic approach to creative problem solving.

(4) Student-centered environment and non-hierarchical teaching styles should be encouraged. For instance, let students involve in the decision-making process.

(5) Teachers should rethink the grading system that welcomes creative performance. In order to spark creativity, evaluating and rewarding creative ideas is important.

(6) Teachers should develop a comfortable, physical, and psychological environment so that students can focus on the creative task.

\section{Learners}

(7) Learners should take active roles to transform their thinking styles with an attitude to think outside the box and play different ideas.

(8) Find a great teacher or mentor to facilitate your creative achievement. 


\section{Conclusion}

Why is it necessary to foster creative thought? Why bother for adult learners? As Warner and Myers (2009) noted, "fundamental to living in the conceptual age will be the use of creativity" (p. 29). In fact, "creativity is woven into the fabric of the American dream" (Niu \& Sternberg, 2003, p. 112). For educators, it is important to encourage creativity for students because "act creatively is essential for the advancement of a civil society" (Harding, 2010, p. 52). For the adult educators, it is also imperative to promote creativity for the sake of providing a scaffold for adult learners to fit in this "postmodern context." Above all, teachers should take an active role in formulating approaches in relation to the nature of creative individuals and creative enterprise. For example, Torrance (1977) observed that "one of the most obvious ways of providing conditions for creative learning is to offer a curriculum with plenty of opportunities for creative behavior" (p. 25).

"All innovation begins with creative ideas" (Amabile et al., 1996, p. 1154). Creativity as a significant reference to comprehension of organizational change may ultimately have an impact on organizational success and survival (Woodman et al., 1993). In the same thread, on the individual level, the creativity asset holding by adult learners is also a successful key to survive in this fast-changing milieu. On a practical level, it is suggested that promoting more successful creativity in adult learning classrooms across all subject areas should be observed and documented. This would be useful to other teachers at various points in their journey of teaching creativity in order to highlight effective pedagogy for moving forward. "We all harbor within us creative seeds that are capable of flourishing" (Edelson, 1999, p. 7). So it is time to let adult learners' creative seeds burst.

\section{References}

Amabile, T. M. (1996). Creativity in context: Update to the social psychology of creativity. Boulder, Colorado: Westview Press.

Amabile, T. M. (1998). How to kill creativity. Harvard Business Review, 76(5), 76-87.

Amabile, T. M., Ccoti, R., Coon, H., Lazenby, J., \& Herron, M. (1996). Assessing the work environment for creativity. Academy of Management Journal, 39(5), 1154-1184.

Barron, F., \& Harrington, D. M. (1981). Creativity, intelligence, and personality. Annual Review of Psychology, 32(1), 439-476.

Batey, M., \& Furnham, A. (2006). Creativity, intelligence, and personality: A critical review of the scattered literature. Genetic, Social \& General Psychology Monographs, 132(4), 355-429.

Beghetto, R. A. (2006). Creative self-efficacy: Correlates in middle and secondary students. Creativity Research Journal, 18(4), 447-457. http://dx.doi.org/10.1207/s15326934crj1804_4

Ch.vez-Eakle, R., Lara, M., \& Cruz-Fuentes, C. (2006). Personality: A possible bridge between creativity and psychopathology? Creativity Research Journal, 18(1), 27-38. http://dx.doi.org/10.1207/s15326934crj1801_4

Craft, A., Gardner, H., \& Claxton, G. (2008). Nurturing creativity, wisdom, and trusteeship in education. In A. Craft, H. Gardner, \& G. Claxton (Eds.), Creativity, wisdom, and trusteeship (pp. 1-13). Thousand Oaks, CA: Corwin Press.

Cummings, A., \& Oldham, G. R. (1997). Enhancing creativity: Managing work contexts for the high potential employee. California Management Review, 40(1), 22-38.

Dineen, R., \& Collins, E. (2005). Killing the goose: Conflicts between pedagogy and politics in the delivery of a creative education. International Journal of Art and Design Education, 24(1), 43-52. http://dx.doi.org/10.1111/j.1476-8070.2005.00422.x

Dineen, R., Samuel, E., \& Livesey, K. (2005). The promotion of creativity in learners: Theory and practice. Art, Design \& Communication in Higher Education, 4(3), 155-172. http://dx.doi.org/10.1386/adch.4.3.155/1

Edelson, P. (1999). Creativity and adult education. New Directions for Adult \& Continuing Education, 81(1), 3-13.

Ekvall, G., \& Ryhammar, L. (1999). The creative climate: Its determinants and effects at a Swedish university. Creativity Research Journal, 12(4), 303-310. http://dx.doi.org/10.1207/s15326934crj1204_8

Feldman, D., \& Benjamin, A. C. (2006). Creativity and education: An American retrospective. Cambridge Journal of Education, 36(3), 319-336. http://dx.doi.org/10.1080/03057640600865819

Ford, C. M. (1996). A theory of individual creative action in multiple social domains. Academy of Management. The Academy of Management Review, 21(4), 1112-1142. 
Gardner, H. (1993). Creating minds: An anatomy of creativity as seen through the lives of Freud, Einstein, Picasso, Stravinsky, Eliot, Graham, and Gandhi. New York: Basic Books.

Harding, T. (2010). Fostering creativity for leadership and leading change. Arts Education Policy Review, 111(2), 51-53. http://dx.doi.org/10.1080/10632910903455827

Hennessey, B. A. (2003). The social psychology of creativity. Scandinavian Journal of Educational Research, 47(3), 253-27. http://dx.doi.org/10.1080/00313830308601

Hickson, J., \& Housley, W. (1997). Creativity in later life. Educational Gerontology, 23(6), 539-547.

Hsen-Hsing, M. (2006). A synthetic analysis of the effectiveness of single components and packages in creativity training programs. Creativity Research Journal, 18(4), 435-446. http://dx.doi.org/10.1207/s15326934crj1804_3

Hunter, S. T., Bedell, K. E., \& Mumford, M. D. (2007). Climate for creativity: A quantitative review. Creativity Research Journal, 19(1), 69-90. http://dx.doi.org/10.1080/10400410709336883

James, K., \& Asmus, C. (2000). Personality, cognitive skills, and creativity in different life domains. Creativity Research Journal, 13(2), 149-159. http://dx.doi.org/10.1207/S15326934CRJ1302_3

Kim, T., Hon, A. Y., \& Deog-Ro, L. (2010). Proactive personality and employee creativity: The effects of job creativity requirement and supervisor support for creativity. Creativity Research Journal, 22(1), 37-45. http://dx.doi.org/10.1080/10400410903579536

Kurtzberg, T. R., \& Amabile, T. M. (2001). From Guilford to creative synergy: Opening the black box of team-level creativity. Creativity Research Journal, 13(3/4), 285-294. http://dx.doi.org/10.1207/S15326934CRJ1334_06

Lin, Y. S. (2011). Fostering creativity through education: A conceptual framework of creative pedagogy. Creative Education, 2(3), 149-155. http://dx.doi.org/10.4236/ce.2011.23021

Lones, P. S. (2000). Learning as creativity: Implications for adult learners. Adult Learning, 11(4), 9-12.

Magno, C. (2009). Explaining the creative mind. International Journal of Research \& Review, 3(1), 10-19.

Mouchiroud, C., \& Lubart, T. (2002). Social creativity: A cross-sectional study of 6- to 11-year-old children. International Journal of Behavioral Development, 26(1), 60-69. http://dx.doi.org/10.1177/016502540202600111

Mumford, M. D. (1995). Situational influences on creative achievement: Attributions or interactions? Creativity Research Journal, 8(4), 405-412. http://dx.doi.org/10.1207/s15326934crj0804_7

Mumford, M. D. (2000). Managing creative people: Strategies and tactics for innovation. Human Resource Management Review, 10(3), 313-351. http://dx.doi.org/10.1016/S1053-4822(99)00043-1

Mumford, M. D., Hunter, S. T., \& Byrne, C. L. (2009). What is the fundamental? The role of cognition in creativity and innovation. Industrial \& Organizational Psychology, 2(3), 353-356. http://dx.doi.org/10.1111/j.1754-9434.2009.01158.x

Mumford, M. D., Mobley, M. I., Uhlman, C. E., Reiter-Palmon, R., \& Doares, L. M. (1991). Process analytic models of creative capacities. Creativity Research Journal, 4(2), 91-122. http://dx.doi.org/10.1080/10400419109534380

National Advisory Committee on Creative and Cultural Education (1999). All our futures: Creativity, culture \& education. Sudbury, Suffolk: Department for Education and Employment.

Newton, D. P., \& Newton, L. D. (2009). Some student teachers' conceptions of creativity in school science. Research in Science \& Technological Education, 27(1), 45-60. http://dx.doi.org/10.1080/02635140802658842

Nilson, L. B. (2010). Teaching at its best: A research-based resource for college

instructors (3rd ed.). San Francisco: Jossey-Bass.

Niu, W., \& Sternberg, R. J. (2003). Societal and school influences on student creativity: The case of China. Psychology in the Schools, 40(1), 103-114. http://dx.doi.org/10.1002/pits.10072

Niu, W., \& Sternberg, R. J. (2006). The philosophical roots of Western and Eastern conceptions of creativity. Journal of Theoretical and Philosophical Psychology, 26(1), 18-38. http://dx.doi.org/10.1037/h0091265

Oldham, G. R., \& Cummings, A. (1996). Employee creativity: Personal and contextual factors at work. Academy of Management Journal, 39(3), 607-634. 
Parker, J. (2005). A consideration of the relationship between creativity and approaches to learning in art and design. International Journal of Art \& Design Education, 24(2), 186-198. http://dx.doi.org/10.1111/j.1476-8070.2005.00439.x

Plato (1979). The Laws. New York, NY: Basic Books.

Prabhu, V., Sutton, C., \& Sauser, W. (2008). Creativity and certain personality traits: Understanding the mediating effect of intrinsic motivation. Creativity Research Journal, 20(1), 53-66. http://dx.doi.org/10.1080/10400410701841955

Runco, M. A. (2003). Education for creative potential. Scandinavian Journal of Educational Research, 47(3), 317-324.

Runco, M. A. (2004). Creativity. Annual Review of Psychology, 55(1), 657-687. http://dx.doi.org/10.1146/annurev.psych.55.090902.141502

Ruscio, A., \& Amabile, T. M. (1999). Effects of instructional style on problem-solving creativity. Creativity Research Journal, 12(4), 251-266. http://dx.doi.org/10.1207/s15326934crj1204_3

Shaheen, R. (2010). Creativity and education. Creative Education, 11(3), 166-169. http://dx.doi.org/10.4236/ce.2010.13026

Shalley, C. E. (1995). Effects of coaction, expected evaluation, and goal setting on creativity and productivity. Academy of Management Journal, 38(2), 483-503.

Simonton, D. K. (2006). Creative genius, knowledge, and reason: The lives and works of eminent creators. In J. C. Kaufman \& J. Baer (Eds.), Creativity and reason in cognitive development (pp. 43-59). New York, NY: Cambridge University Press.

Sosik, J. J., Kahai, S. S., \& Avolio, B. J. (1998). Transformational leadership and dimensions of creativity: Motivating idea generation in computer-mediated groups. Creativity Research Journal, 11(2), 111-121. http://dx.doi.org/10.1207/s15326934crj1102_3

Sternberg, R. J. (2006). The nature of creativity. Creativity Research Journal, 18(1), 87-98. http://dx.doi.org/10.1207/s15326934crj1801_10

Tierney, P., Farmer, S. M., \& Graen, G. B. (1999). An examination of leadership and employee creativity: The relevance of traits and relationships. Personnel Psychology, 52(3), 591-620. http://dx.doi.org/10.1111/j.1744-6570.1999.tb00173.x

Torrance, P. E. (1977). Creativity in the classroom: What research says to the teacher? West Haven, CT: National Education Association.

Torrance, E. P. (1995). Why fly? A philosophy of creativity. Norwood, NJ: Ablex.

Wallas, G. (1926). The art of thought. New York: Harcourt Brace Jovanovich.

Warner, S. A., \& Myers, K. L. (2009). The creative classroom: The role of space and place toward facilitating creativity. Technology Teacher, 69(4), 28-34.

Welkener, M. M. (2004). Helping students develop vision and voice. About Campus, 8(6), 12-17.

Williams, S. D. (2004). Personality, attitude, and leader influences on divergent thinking and creativity in organizations. European Journal of Innovation Management, $7(3)$, 187-204. http://dx.doi.org/10.1108/14601060410549883

Wilson, H. (2009). The Picasso in your classroom: How to meet the needs of talented artists in elementary school. Gifted Child Today, 32(1), 36-41.

Woodman, R. W., Sawyer, J. E., \& Griffin, R. W. (1993). Toward a theory of organizational creativity. The Academy of Management Review, 18(2), 293-321.

Ya-Hui, S. (2009). Idea creation: The need to develop creativity in lifelong learning practices. International Journal of Lifelong Education, 28(6), 705-717. http://dx.doi.org/10.1080/02601370903293161

Zimmerman, E. (2009). Reconceptualizing the role of creativity in art education theory and practice. Studies in Art Education, 50(4), 382-399. 